\title{
Correction to: Allogeneic hematopoietic stem cell transplantation in elderly patients with acute myeloid leukemia or myelodysplastic syndromes: myth and reality
}

A. Sutra Del Galy (D) A. Marouf - E. Raffoux - M. Robin - D. Michonneau (D) M. Sébert - F. Sicre de Fontebrune •

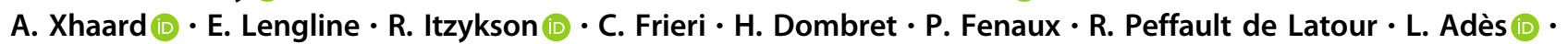
G. Socié (iD)

Published online: 9 February 2021

(c) The Author(s), under exclusive licence to Springer Nature Limited 2021

Correction to: Leukemia

https://doi.org/10.1038/s41375-020-1004-9

The original version of this article unfortunately contained a mistake. The title was incorrect. The corrected title is given below.
Allogeneic hematopoietic stem cell transplantation in elderly patients with acute myeloid leukemia or myelodysplastic syndromes: myth and reality

The original article has been corrected. 